Original Research

\title{
In Vitro Assessment of Fecal Inocula From Horses Fed on High-Fiber Diets With Fibrolytic Enzymes Addition on Gas, Methane, and Carbon Dioxide Productions as Indicators of Hindgut Activity
}

\author{
Ahmed E. Kholif ${ }^{a}$, Luis A. Baza-García ${ }^{\mathrm{b}}$, Mona M.Y. Elghandour ${ }^{\mathrm{b}}$, \\ Abdelfattah Z.M. Salem ${ }^{\mathrm{b}, *}$, Alberto Barbabosa ${ }^{\mathrm{b}}$, Ignacio A. Dominguez-Vara ${ }^{\mathrm{b}}$, \\ Juan E. Sanchez-Torres ${ }^{\text {b }}$ \\ ${ }^{a}$ Dairy Science Department, National Research Centre, Giza, Egypt \\ ${ }^{\mathrm{b}}$ Facultad de Medicina Veterinaria y Zootecnia, Universidad Autónoma del Estado de México, Toluca, México
}

\section{A R T I C L E I N F O}

\section{Article history:}

Received 17 October 2015

Received in revised form 5 November 2015 Accepted 5 November 2015

Available online 14 November 2015

\section{Keywords:}

Fibrolytic enzymes

Fecal inoculum

In vitro gas production

Methane production

\begin{abstract}
A B S T R A C T
The aim of this study was to assess the effect of fecal inocula from horses fed on concentrate (restricted amount daily) and oat straw (ad libitum) supplemented with fibrolytic enzymes on in vitro hindgut activity. Cellulase (CE), xylanase (XY), and CE $+\mathrm{XY}$ $(1: 1 \mathrm{vol} / \mathrm{vol} ; \mathrm{CX})$ were tested at three levels $(\mu \mathrm{L} / \mathrm{g}$ dry matter [DM]): 0,1 , and 3 , in addition to control without enzyme addition. Fecal inocula were collected from 16 Quarter Horse mares supplemented with enzyme at 0 (without enzyme), or fed 5-mL enzyme/mare/d of CE (FCE), XY (FXY), or CE + XY (1:1 vol/vol; FCX) for 15 days. The fecal content mixed with the culture media were used for incubation in bottles containing 1-g DM of substrate (a mixture of concentrate and oat straw [1:1 DM]). Gas (GP), methane $\left(\mathrm{CH}_{4}\right)$, and carbon dioxide productions were measured at $2,4,6,8,10,12,24$, and 48 hours after incubation. Interactions occurred $(P<.05)$ between fecal source $\times$ enzyme product for the asymptotic $\mathrm{GP}$, the rate of $\mathrm{GP}, \mathrm{CH}_{4}$ production, and fermentation kinetic parameters. Moreover, interactions were observed $(P<.05)$ between fecal source $\times$ enzyme product $\times$ enzyme dose for the rate of GP, $\mathrm{CH}_{4}$ production, and DM digestibility. Xylanase at 3- $\mu \mathrm{L} / \mathrm{g}$ DM with FXY fecal increased $(P<.05)$ the asymptotic GP, short-chain fatty acids, and microbial protein productions with lowering $(P<.05)$ partitioning factor. At 24 and 48 hours and without enzyme, FCX and FXY, had the highest $(P<.05) \mathrm{CH}_{4}$ production. It can be concluded that $\mathrm{XY}$ enzyme at $3-\mu \mathrm{L} / \mathrm{g}$ DM was the most effective compared with other treatments.
\end{abstract}

(c) 2016 Elsevier Inc. All rights reserved.

\section{Introduction}

Feeding horses on fibrous diets is important to overcome some feeding disorders such as gastric ulceration,

\footnotetext{
* Corresponding author at: Abdelfattah Z.M. Salem, Facultad de Medicina Veterinaria y Zootecnia, Universidad Autónoma del Estado de México, 50000 Toluca, México.

E-mail address: asalem70@yahoo.com (A.Z.M. Salem).
}

hindgut acidosis, laminitis, and colic associated with highstarch diets [1]. Such disorders could impair the fibrolytic activity in the horse's hindgut and cause microbial profile disturbance with the proliferation of Streptococcus bovis as the dominant microbe causing a reduced energy yield of the fed diet [2] and reducing whole-diet digestibility. However, fibrous feeds are characterized by poor palatability, high lignocellulose content, low nutrient digestibility, and low crude protein (CP) content $[3,4]$. 
Feeding horses a minimum of $1 \%$ of their body weight (BW) as fibers can minimize occurrence of such disorders [5]. Oat straw is one of the most common agriculture residues in Mexico with low nutritive value as low protein content and low nutrients digestibility and with about 11.2 million of tones produced during 2013. Therefore, there is a need to develop feeding strategies that meet the energy requirements of the horse fed high-fiber diets and maintain gut health and integrity [6]. For an effective utilization of fibrous feeds, exogenous fibrolytic enzymes have been used to improve carbohydrate and cell wall degradation in ruminants $[7,8]$ and in equines [9].

In ruminants, supplementing diets with fibrolytic enzymes has been shown to improve feed utilization and animal performance $[10,11]$. Supplementing the diet of horses with exogenous fibrolytic enzymes has gained substantial interest in recent years [9,12]. Because the large intestine in the horses is a fermentation system similar to the rumen [13], improvements in feed utilization and animal performance should be expected with horses with fibrolytic enzymes supplementation. In the rumen of ruminants and in the cecum of equines, living microorganisms give them the ability to break down fibers to meet their energy demands. Consequently, the application of exogenous enzymes to fibrous feeds may help release starches, sugars, proteins, vitamins, and minerals for digestion and absorption in the small intestine [14]. However, the potential of exogenous enzymes to enhance the digestion of fibers in the hindgut of the equine is inconclusive. Salem et al [9] observed in vivo improved neutral detergent fiber (NDF) and acid detergent fiber (ADF) digestion of oat straw when mares were fed fibrous diet supplemented with fibrolytic enzymes. In contrast, Murray et al [12] reported a significant reduction in in vivo digestibility of the fibrous fractions of enzyme-treated diets.

Therefore, the aim of the present study was to assess the effect of fecal inocula from horses supplemented with exogenous fibrolytic enzymes in diets on in vitro total gas (GP), methane $\left(\mathrm{CH}_{4}\right)$, and carbon dioxide $\left(\mathrm{CO}_{2}\right)$ productions as indicators of hindgut activity of a diet containing $50 \%$ oat straw.

\section{Materials and Methods}

\subsection{Substrate and Enzyme Products}

A basal diet consisting of a mixture of concentrate and oat straw (1:1 dry matter [DM]) was used as the substrate for the incubations. The concentrate portion contained 50\% commercial concentrate (Pell Roll Cuarto de Milla, Mexico) and $50 \%$ wheat bran which contained $(\mathrm{g} / \mathrm{kg} \mathrm{DM})$ the following: organic matter (OM): 901.8, CP: 112.0, NDF: 511.0, and ADF: 202.8. The chemical composition (g/kg DM) of the oat straw was as follows: OM: 929.4, CP: 26.7, NDF: 668.7, and ADF: 405.0.

Cellulase plus (CE) and xylanase plus (XY) (Dyadic PLUS; Dyadic international, Inc, Jupiter, FL, USA) were used. The enzyme activities of the enzyme products were assayed for endoglucanase and XY activity as described by Robyt and Whelan [15]. The CE product contained 30,000 to $36,000 \mathrm{U}$ of $\mathrm{CE} / \mathrm{g}$ and 7,500 to $10,000 \mathrm{U}$ of beta-glucanase/g. The XY product contained 34,000 to $41,000 \mathrm{U}$ of $\mathrm{XY} / \mathrm{g}, 12,000$ to 15,000 units of beta-glucanase/g, and 45,000 to $55,000 \mathrm{U}$ of $\mathrm{CE} / \mathrm{g}$.

\subsection{In Vitro Fecal Incubations}

Before the start of the experiment, fecal contents (i.e., the inoculum source) were collected from 16 Quarter Horse mares ( 450 to $500 \mathrm{~kg} \mathrm{BW}$; aged 10 to 12 years) used in the in vivo experiment of Salem et al [9] offered the same basal diet of a mixture of concentrate (restricted amount daily) and oat straw (ad libitum) at 1:1 DM that was used as a substrate for the in vitro incubations as described previously. However, the mares consumed the offered concentrates and oat hay at about 2:1 DM, respectively. The mare's daily diets were supplemented with $\mathrm{CE}, \mathrm{XY}$, or CE + XY (1:1 $\mathrm{vol} / \mathrm{vol}$; $\mathrm{CX}$ ) at $5 \mathrm{~mL} / \mathrm{mare} / \mathrm{d}$ for 15 days.

Four composited fecal contents samples, collected from the rectum of each mare before the morning feeding on the last day (i.e., day 15), were used for the in vitro incubation. About $10 \%$ of individual fecal samples of each mare within each treatment were mixed and homogenized to obtain a homogenized sample of feces of each treatment. The four fecal treatments were compared in the presence of three levels of each enzyme product: fecal from mares fed control diet without enzyme addition (FCO) and without enzyme addition (EP0) before incubation, fecal from mares fed CE (FCE) and with CE addition before incubation, fecal from mares fed XY (FXY) and with XY addition before incubation, or fecal from mares fed CE $+\mathrm{XY}$ at $1: 1 \mathrm{vol} / \mathrm{vol}(\mathrm{FCX})$ and with $C E+X Y(1: 1 \mathrm{vol} / \mathrm{vol})$ addition before incubation. With the exception of the preparation of the microbial inocula, the method of Theodorou et al [16] was used to measure GP. Briefly, a subsample of the composite fecal contents of each treatment was mixed with the Goering and Van Soest [17] buffer solution without trypticase in the ratio of $1: 4 \mathrm{vol} / \mathrm{vol}$. The incubation media were mixed and strained through four layers of cheesecloth into a flask with an $\mathrm{O}_{2}$-free headspace. The fecal content mixed with the culture media was used to inoculate three identical runs of incubation in bottles containing 1-g DM of substrate (a mixture of concentrate and oat straw [1:1 DM]). Oat straw and concentrates were separately grounded through a Wiley mill (Arthur H. Thomas, Philadelphia, PA, USA) using a 2-mm screen and then mixed together before the incubation.

A total number of 252 bottles (three fecal sources $\times$ three enzyme doses [per gram DM: 0,1 , and $3 \mu \mathrm{L}$ ] $\times$ three enzyme products $\times$ three replicates $\times$ three runs + [three replicates of control $\times$ three runs]) plus three bottles without substrate and enzyme as blanks. After bottles filling, they were flushed with $\mathrm{CO}_{2}$ and immediately closed with rubber stoppers, shaken, and placed in an incubator set at $39^{\circ} \mathrm{C}$. Gas, $\mathrm{CH}_{4}$, and $\mathrm{CO}_{2}$ productions were recorded at $2,4,6,8,10,12,24$, and 48 hours after inoculation. Gas production was recorded using the pressure reading technique (Extech instruments, Waltham, MA, USA) of Theodorou et al [16], whereas the $\mathrm{CH}_{4}$ and $\mathrm{CO}_{2}$ productions were recorded using a Gas-Pro detector (Gas Analyzer Crowcon, Model Tetra3, Abingdon, UK). At the end of incubation after 48 hours, bottles were uncapped and the $\mathrm{pH}$ was measured using a digital $\mathrm{pH}$ meter (Conductronic pH15, Puebla, 
Mexico). The content of each bottle was then filtered under vacuum through glass crucibles with a sintered filter and fermentation residues dried at $65^{\circ} \mathrm{C}$ for 72 hours to estimate dry matter disappearance (DMD).

\subsection{Calculations and Statistical Analyses}

To estimate kinetic parameters of GP, gas volumes $(\mathrm{mL} / \mathrm{g}$ DM) were fitted using the NLIN procedure of SAS [18] according to France et al [19] model as:

$y=A \times\left[1-e^{-c(t-L)}\right]$

where $y$ is the volume of GP at time $t(\mathrm{~h}) ; A$ is the asymptotic $\mathrm{GP}(\mathrm{mL} / \mathrm{g} \mathrm{DM}) ; c$ is the fractional rate of fermentation $(/ \mathrm{h})$, and $L(\mathrm{~h})$ is the discrete lag time before any gas is released.

Metabolizable energy (ME, MJ/kg DM) and in vitro OM digestibility (OMD, \%) were estimated according to Menke et al [20] as:

$M E(M J / k g D M)=2.20+0.136 G P+0.057 C P$

OMD $(\%)=14.88+0.889 G P+0.45 C P+0.0651 X A$

where DM, dry matter; $\mathrm{CP}$, crude protein (\%); XA, ash in percent; and GP, the net GP in $\mathrm{mL}$ from 200-mg dry sample after 24 hours of incubation.

The partitioning factor at 24 hours of incubation $\left(\mathrm{PF}_{24}\right)$, as a measure of fermentation efficiency, was calculated as the ratio of in vitro DMD (mg/g DM) to the volume of gas $(\mathrm{mL})$ produced at 24 hours (i.e., DMD/total GP $\left[\mathrm{GP}_{24}\right]$ ) according to Blümmel et al [21].

Gas yields $\left(\mathrm{GY}_{24}\right)$ were calculated as the volume of gas produced after 24 hours ( $\mathrm{mL}$ gas/g DM) of incubation divided by the amount of DMD $(\mathrm{g})$ as:

Gas yields $\left(G Y_{24}\right)=m L$ gas per $g$ DM $/ g D M D$

Short-chain fatty acids (SCFA) were calculated according to Getachew et al [22] as:

SCFA $(\mathrm{mmol} / 200 \mathrm{mgDM})=0.0222 \mathrm{GP}-0.00425$

where GP is 24 hours net GP ( $\mathrm{mL} / 200 \mathrm{mg} \mathrm{DM})$.

Microbial crude protein (MCP) production was calculated according to Blümmel et al [21] as:

$M C P(m g / g D M)=m g D M D-(m L$ gas $\times 2.2 m g / m L)$

where $2.2 \mathrm{mg} / \mathrm{mL}$ is a stoichiometric factor that expresses $\mathrm{mg}$ of $\mathrm{C}, \mathrm{H}$, and $\mathrm{O}$ required for the SCFA gas associated with production of $1 \mathrm{~mL}$ of gas [21].

The data were analyzed with fecal source as a random effect and enzyme product and doses as fixed effects using PROC MIXED procedure of SAS [18] in a randomized block design. Data of each of the three runs for each treatment were averaged before the statistical analysis, and the mean of each individual sample was considered the experimental unit. The statistical model was:

$Y_{i j k l}=\mu+F_{i}+Z_{j}+D_{k}+(F \times Z)_{\mathrm{ij}}+(F \times Z \times D)_{i j k}+E_{i j k l}$

where $Y_{i j k l}=$ is every observation of the $i$ th fecal source $\left(F_{i}\right)$ when incubated in the $j$ th enzyme product $\left(Z_{j}\right)$ and $k$ th enzyme dose $\left(D_{k}\right) ; \mu$ is the general mean; $F_{i}$ is the fecal source effect; $Z_{j}$ is the enzyme product effect; $D_{k}$ is the effect of enzyme dose; $(F \times Z)_{i j}$ is the interaction between fecal source and enzyme product; $(F \times Z \times D)_{i j k}$ is the interaction between fecal source, enzyme product and enzyme dose; and $\mathrm{E}_{\mathrm{ijkl}}$ is experimental error. Linear and quadratic polynomial contrasts were used to examine responses in GP to increasing levels of the enzyme products. Tukey's test was used for the multiple comparisons of means.

\section{Results}

\subsection{Fecal In Vitro Gas Production}

There were interactions $(P<.05)$ between fecal source and enzyme product for the asymptotic GP, the rate of GP, and GP at 2, 4, 6, 8, and 10 hours after incubation. Moreover, three-way interactions were observed $(P<.05)$ between fecal source $\times$ enzyme product $\times$ enzyme dose for the rate of GP and GP at 2 and 4 hours of incubation. Compared with the control treatment (FCO fecal from mares fed without enzyme and without enzyme addition before incubation), $\mathrm{XY}$ addition at $3-\mu \mathrm{L} / \mathrm{g}$ DM with FXY inoculum increased $(P<$ $.05)$ the asymptotic GP and GP until 8 hours of incubation. Enzymes addition had no effects $(P>.05)$ on the rate of GP and lag time (Table 1 ).

\subsection{Methane and Carbon Dioxide Productions}

Interactions were observed $(P<.05)$ between fecal source $\times$ enzyme product, and between fecal source $\times$ enzyme product $\times$ enzyme dose at $10,12,24$, and 48 hours of incubation for $\mathrm{CH}_{4}$ production. No $\mathrm{CH}_{4}$ was produced during the first 8 hours of incubation. Methane production started at 10 hours of incubation without significant effect $(P>.05)$ for enzymes or fecal at 10 and 12 hours of incubation. At 24 hours of incubation, FCX inoculum without enzyme had the highest $\mathrm{CH}_{4}$ production $(P=.020)$, whereas FXY inoculum without enzyme addition had greater $(P=.040) \mathrm{CH}_{4}$ production at 48 hours of incubation compared with other treatments (Table 2 ).

There was no interaction observed $(P>.05)$ between fecal source $x$ enzyme product or between fecal source $\times$ enzyme product $\times$ enzyme dose for $\mathrm{CO}_{2}$ production throughout incubation hours. Enzyme addition had no effect $(P>.05)$ on $\mathrm{CO}_{2}$ production throughout incubation hours (Table 3 ).

\subsection{Fermentation Profile}

There was interaction $(P<.05)$ between fecal source $\times$ enzyme product for $\mathrm{pH}, \mathrm{ME}, \mathrm{DMD}, \mathrm{SCF}, \mathrm{PF}_{24}, \mathrm{MCP}$, and $\mathrm{GY}_{24}$. Three-way interaction occurred $(P=.014)$ between fecal source $\times$ enzyme product $\times$ enzyme dose for DMD. Addition of $\mathrm{XY}$ enzyme at $1-\mu \mathrm{L} / \mathrm{g}$ DM linearly increased $\operatorname{DMD}(P=.026)$ with FXY inoculum. Addition of XY enzyme at $3-\mu \mathrm{L} / \mathrm{g}$ DM quadratically increased SCFA production $(P=$ $.043)$ and MCP production $(P=.039)$ with FXY inoculum. The XY treatment had the lowest $\mathrm{PF}_{24}(P=.033)$ compared with other treatments. Enzyme treatments had no effect $(P$ $>$.05) on $\mathrm{pH}, \mathrm{ME}, \mathrm{OMD}$, and $\mathrm{GY}_{24}$ (Table 4). 
Table 1

In vitro fecal gas kinetics and cumulative gas production after 48 hours of incubation as affected by fibrolytic enzymes addition.

\begin{tabular}{|c|c|c|c|c|c|c|c|c|c|c|c|c|c|}
\hline \multirow[t]{2}{*}{ Fecal Source } & \multirow{2}{*}{$\begin{array}{l}\text { Enzyme } \\
\text { Product }\end{array}$} & \multirow{2}{*}{$\begin{array}{l}\text { Enzyme Dose } \\
(\mu \mathrm{L} / \mathrm{g} \mathrm{DM})\end{array}$} & \multicolumn{3}{|l|}{ GP Parameters } & \multicolumn{8}{|c|}{ In Vitro GP (mL/g DM) at: } \\
\hline & & & $A(\mathrm{~mL} / \mathrm{g} \mathrm{DM})$ & $c(/ \mathrm{hr})$ & $L(\mathrm{hr})$ & $2 \mathrm{hr}$ & $4 \mathrm{hr}$ & $6 \mathrm{hr}$ & $8 \mathrm{hr}$ & $10 \mathrm{hr}$ & $12 \mathrm{hr}$ & $24 \mathrm{hr}$ & $48 \mathrm{hr}$ \\
\hline FCO & EP0 & 0 & 292.1 & 0.062 & 0.99 & 34.0 & 64.0 & 90.5 & 113.9 & 134.5 & 152.8 & 225.4 & 276.6 \\
\hline \multirow[t]{3}{*}{ FCE } & $\mathrm{CE}$ & 0 & 340.7 & 0.048 & 1.21 & 30.9 & 59.0 & 84.5 & 107.7 & 128.8 & 147.9 & 231.2 & 305.0 \\
\hline & & 1 & 341.3 & 0.041 & 1.80 & 26.5 & 50.9 & 73.3 & 93.9 & 112.9 & 130.4 & 209.9 & 288.9 \\
\hline & & 3 & 346.6 & 0.043 & 1.42 & 29.4 & 56.3 & 80.9 & 103.5 & 124.2 & 143.1 & 228.2 & 311.0 \\
\hline \multirow[t]{3}{*}{ FCX } & $\mathrm{CX}$ & 0 & 249.9 & 0.069 & 1.24 & 31.8 & 59.5 & 83.6 & 104.7 & 123.0 & 139.1 & 200.4 & 239.9 \\
\hline & & 1 & 276.3 & 0.057 & 1.53 & 29.6 & 56.0 & 79.6 & 100.7 & 119.4 & 136.2 & 205.0 & 257.7 \\
\hline & & 3 & 276.5 & 0.063 & 1.26 & 32.4 & 60.9 & 86.1 & 108.4 & 128.0 & 145.3 & 214.2 & 262.3 \\
\hline \multirow[t]{3}{*}{ FXY } & $X Y$ & 0 & 358.0 & 0.041 & 1.45 & 27.7 & 53.3 & 76.8 & 98.4 & 118.4 & 136.8 & 220.5 & 303.9 \\
\hline & & 1 & 384.6 & 0.061 & 1.12 & 32.8 & 61.8 & 87.4 & 110.0 & 130.0 & 147.7 & 218.3 & 268.7 \\
\hline & & 3 & 396.0 & 0.074 & 1.58 & 42.0 & 78.3 & 109.6 & 136.5 & 159.8 & 179.9 & 254.0 & 297.2 \\
\hline SEM & & & 17.88 & 0.0045 & 0.312 & 2.33 & 4.29 & 5.93 & 7.30 & 8.44 & 9.39 & 12.50 & 14.21 \\
\hline \multicolumn{14}{|l|}{$P$ value } \\
\hline \multicolumn{14}{|l|}{ Enzyme Dose } \\
\hline Linear & & & .012 & .053 & .606 & .032 & .037 & .043 & .050 & .059 & .069 & .165 & .541 \\
\hline Quadratic & & & .235 & .355 & .572 & .116 & .119 & .122 & .124 & .127 & .129 & .139 & .159 \\
\hline Fecal Source & $\times$ Enzyme & Product & .001 & .001 & .057 & .010 & .015 & .023 & .034 & .049 & .067 & .172 & .621 \\
\hline $\begin{array}{l}\text { Fecal Source } \\
\text { Enzyme Do }\end{array}$ & $\begin{array}{l}\times \text { Enzyme } \\
\text { se }\end{array}$ & Product $\times$ & .074 & .002 & .396 & .030 & .042 & .060 & .085 & .118 & .161 & .573 & .485 \\
\hline
\end{tabular}

Abbreviations: A, asymptotic gas production; $c$, rate of gas production; CE, cellulase; CX, cellulase + xylanase (1:1); DM, dry matter; FCE, fecal from horses fed cellulase; FCO, fecal from horses fed control diet; FCX, fecal from horses fed cellulase + xylanase (1:1); FXY, fecal from horses fed xylanase; GP, gas production; $L$, initial delay before gas production begins; SEM, standard error of the mean; XY, xylanase.

\section{Discussion}

The in vitro fermentation technique is a simple, powerful, and sensitive screening tool for evaluating substrate fermentation and for testing the efficacy of feed additives. Like in ruminants, the technique can be used for studying the nutritive value of equine diet using either cecal contents or feces as a source of inoculum [13,23]. The use of feces as the source of microbial inoculum for in vitro fermentation has proved to be a successful alternative source of microbial inoculum in equine studies $[13,22]$.

Agazzi et al [24] have showed that the average mean retention time for feed passing through the gut of the horse ranges between 36 and 38 hours; however, in the present in vitro study, incubations were extended to 48 hours.
Addition of CE or XY resulted in inconsistent fermentation kinetics and GP results probably due to the enzyme activities and the diets of inoculum donor animals $[25,26]$.

\subsection{In Vitro Fecal Gas Production}

The occurrence of interactions between fecal source and enzyme product suggests that the asymptotic GP, the rate of GP, and gas volumes are fecal source and enzyme product dependent. The fermentation of the diet depends on many factors including the diet and nutrient availability for inocula microorganisms during fermentation $[9,23]$. Availability of nutrients for inocula activity and growth will stimulate the degradability of different nutrients [23].

Table 2

In vitro fecal methane production after 48 hours of incubation as affected by fibrolytic enzymes addition.

\begin{tabular}{|c|c|c|c|c|c|c|c|c|c|c|}
\hline \multirow[t]{2}{*}{ Fecal Source } & \multirow[t]{2}{*}{ Enzyme Product } & \multirow{2}{*}{$\begin{array}{l}\text { Enzyme Dose } \\
(\mu \mathrm{L} / \mathrm{g} \mathrm{DM})\end{array}$} & \multicolumn{8}{|c|}{ In Vitro Methane Production (mL/g DM) at: } \\
\hline & & & $2 \mathrm{hr}$ & $4 \mathrm{hr}$ & $6 \mathrm{hr}$ & $8 \mathrm{hr}$ & $10 \mathrm{hr}$ & $12 \mathrm{hr}$ & $24 \mathrm{hr}$ & $48 \mathrm{hr}$ \\
\hline FCO (control) & EP0 (without enzyme) & 0 & 0.00 & 0.00 & 0.00 & 0.00 & 0.00 & 0.00 & 1.04 & 1.52 \\
\hline \multirow[t]{3}{*}{ FCE } & $\mathrm{CE}$ & 0 & 0.00 & 0.00 & 0.00 & 0.00 & 0.00 & 0.14 & 0.83 & 1.09 \\
\hline & & 1 & 0.00 & 0.00 & 0.00 & 0.00 & 0.18 & 0.64 & 0.80 & 0.80 \\
\hline & & 3 & 0.00 & 0.00 & 0.00 & 0.00 & 0.32 & 0.84 & 1.19 & 2.92 \\
\hline \multirow[t]{3}{*}{ FCX } & $\mathrm{CX}$ & 0 & 0.00 & 0.00 & 0.00 & 0.00 & 0.12 & 0.12 & 2.95 & 3.71 \\
\hline & & 1 & 0.00 & 0.00 & 0.00 & 0.00 & 0.00 & 0.00 & 1.11 & 4.13 \\
\hline & & 3 & 0.00 & 0.00 & 0.00 & 0.00 & 0.20 & 0.20 & 1.00 & 2.50 \\
\hline \multirow[t]{4}{*}{ FXY } & $X Y$ & 0 & 0.00 & 0.00 & 0.00 & 0.00 & 0.33 & 0.98 & 2.27 & 7.47 \\
\hline & & 1 & 0.00 & 0.00 & 0.00 & 0.00 & 0.11 & 0.36 & 0.92 & 3.09 \\
\hline & & 3 & 0.00 & 0.00 & 0.00 & 0.00 & 0.25 & 0.25 & 2.75 & 4.26 \\
\hline & & & 0.00 & 0.00 & 0.00 & 0.00 & 0.00 & 0.14 & 0.83 & 1.09 \\
\hline SEM & & & 0.000 & 0.000 & 0.000 & 0.000 & 0.062 & 0.051 & 0.039 & 0.049 \\
\hline \multicolumn{11}{|l|}{ Enzyme Dose } \\
\hline Linear & & & 1.000 & 1.000 & 1.000 & 1.000 & 0.427 & 0.658 & 0.579 & 0.774 \\
\hline Quadratic & & & 1.000 & 1.000 & 1.000 & 1.000 & 0.363 & 0.914 & 0.020 & 0.040 \\
\hline \multicolumn{3}{|c|}{ Fecal Source $\times$ Enzyme Product } & 1.000 & 1.000 & 1.000 & 1.000 & 0.007 & 0.030 & $<0.001$ & $<0.001$ \\
\hline \multicolumn{3}{|c|}{ Fecal Source $\times$ Enzyme Product $\times$ Enzyme Dose } & 1.000 & 1.000 & 1.000 & 1.000 & 0.010 & 0.038 & 0.009 & 0.005 \\
\hline
\end{tabular}

Abbreviations: CE, cellulase; CX, cellulase + xylanase (1:1); DM, dry matter; FCE, fecal from horses fed cellulase; FCO, fecal from horses fed control diet; FCX, fecal from horses fed cellulase + xylanase (1:1); FXY, fecal from horses fed xylanase; SEM, standard error of the mean; XY, xylanase. 
Table 3

In vitro fecal carbon dioxide production after 48 hours of incubation as affected by fibrolytic enzymes addition.

\begin{tabular}{|c|c|c|c|c|c|c|c|c|c|c|}
\hline \multirow[t]{2}{*}{ Fecal Source } & \multirow{2}{*}{$\begin{array}{l}\text { Enzyme } \\
\text { product }\end{array}$} & \multirow{2}{*}{$\begin{array}{l}\text { Enzyme Dose } \\
(\mu \mathrm{L} / \mathrm{g} \mathrm{DM})\end{array}$} & \multicolumn{8}{|c|}{ In vitro carbon dioxide production $(\mathrm{mL} / \mathrm{g} \mathrm{DM})$ at: } \\
\hline & & & 2 hours & 4 hours & 6 hours & 8 hours & 10 hours & 12 hours & 24 hours & 48 hours \\
\hline FCO (control) & $\begin{array}{c}\text { EP0 (without } \\
\text { enzyme) }\end{array}$ & 0 & 10.0 & 11.2 & 24.4 & 37.0 & 40.2 & 45.6 & 61.4 & 83.7 \\
\hline \multirow[t]{3}{*}{ FCE } & $\mathrm{CE}$ & 0 & 15.0 & 31.4 & 32.0 & 36.2 & 39.1 & 42.7 & 69.3 & 96.0 \\
\hline & & 1 & 10.8 & 19.8 & 27.3 & 32.6 & 33.5 & 37.8 & 63.8 & 96.4 \\
\hline & & 3 & 8.3 & 18.8 & 22.8 & 32.7 & 37.6 & 42.5 & 64.2 & 80.5 \\
\hline \multirow[t]{3}{*}{ FCX } & $\mathrm{CX}$ & 0 & 16.6 & 20.5 & 23.8 & 33.2 & 39.1 & 43.5 & 69.6 & 78.1 \\
\hline & & 1 & 10.8 & 22.7 & 29.7 & 32.7 & 35.6 & 44.9 & 61.9 & 70.5 \\
\hline & & 3 & 16.5 & 26.5 & 29.9 & 32.4 & 38.2 & 45.7 & 56.7 & 77.8 \\
\hline \multirow[t]{3}{*}{ FXY } & $\mathrm{XY}$ & 0 & 15.1 & 18.1 & 23.2 & 29.7 & 35.6 & 49.5 & 64.5 & 91.9 \\
\hline & & 1 & 8.9 & 18.4 & 21.3 & 38.5 & 39.4 & 44.8 & 60.3 & 83.8 \\
\hline & & 3 & 9.4 & 21.1 & 31.7 & 38.8 & 45.7 & 56.2 & 67.7 & 82.4 \\
\hline SEM & & & 3.08 & 4.00 & 8.00 & 9.12 & 8.31 & 7.26 & 8.46 & 10.65 \\
\hline \multicolumn{11}{|l|}{ Enzyme Doses: } \\
\hline Linear & & & 0.584 & 0.797 & 0.74 & 0.792 & 0.966 & 0.815 & 0.95 & 0.455 \\
\hline Quadratic & & & 0.999 & 0.885 & 0.624 & 0.621 & 0.941 & 0.528 & 0.622 & 0.55 \\
\hline Fecal Source $\times$ Enzyme Product & & & 0.053 & 0.187 & 0.056 & 0.231 & 0.316 & 0.086 & 0.223 & 0.447 \\
\hline $\begin{array}{l}\text { Fecal Source } \times \text { Enzyme Product } \times \\
\text { Enzyme Dose }\end{array}$ & & & 0.465 & 0.053 & 0.108 & 0.262 & 0.06 & 0.086 & 0.42 & 0.142 \\
\hline
\end{tabular}

Abbreviations: CE, cellulase; CX, cellulase + xylanase (1:1); DM, dry matter; FCE, fecal from horses fed cellulase; FCO, fecal from horses fed control diet; FCX, fecal from horses fed cellulase + xylanase (1:1); FXY, fecal from horses fed xylanase; SEM, standard error of the mean; XY, xylanase.

Xylanase addition at 3- $\mu \mathrm{L} / \mathrm{g}$ DM increased GP without affecting the lag time or the rate of GP, which suggests a stimulated fecal fermentation. As GP is closely correlated with the amount of feed fermented, these findings suggest that XY enzyme could degrade some cell wall constituents and facilitate the access of fecal microorganisms [27]. Fibrolytic enzyme (e.g., XY enzyme) can stimulate fibrolytic and nonfibrolytic bacteria due to release of carbohydrates from feeds that are readily used by the bacteria [28]. Addition of fibrolytic enzymes facilitates the access of microorganisms to feed components enabling a faster microbial growth [27]. In their study, Mao et al [25] observed that addition of $\mathrm{XY}$ enzyme increased the numbers of total bacteria and Fibrobacter succinogenes in the incubation medium and improved in vitro fermentation. Different GP with different enzyme doses support the hypothesis that a suitable enzyme level could improve the fermentation of feeds during the initial stages of fiber digestion [9].

\subsection{Methane and Carbon Dioxide Productions}

Enzyme addition had no effect on $\mathrm{CO}_{2}$ production throughout the incubation. However, some interactions between fecal source $\times$ enzyme product $\times$ enzyme dose were observed. Interaction occurrence showed that $\mathrm{CH}_{4}$ production is fecal source, enzyme product, and enzyme dose dependent. To our knowledge, very few numbers of experiments studied the effect of fibrolytic enzymes on $\mathrm{CH}_{4}$ production from equines compared with ruminants [9].

Table 4

In vitro fecal fermentation profile after 48 hours of incubation as affected by fibrolytic enzymes addition.

\begin{tabular}{|c|c|c|c|c|c|c|c|c|c|c|}
\hline Fecal Source & $\begin{array}{l}\text { Enzyme } \\
\text { Product }\end{array}$ & $\begin{array}{l}\text { Enzyme Dose } \\
(\mu \mathrm{L} / \mathrm{g} \mathrm{DM})\end{array}$ & $\mathrm{pH}$ & $\begin{array}{l}\mathrm{ME} \\
(\mathrm{MJ} / \mathrm{kg} \mathrm{DM})\end{array}$ & $\begin{array}{l}\text { OMD } \\
(\mathrm{mg} / \mathrm{g} \mathrm{DM})\end{array}$ & $\begin{array}{l}\text { DMD } \\
(\mathrm{mg} / \mathrm{g} \mathrm{DM})\end{array}$ & $\begin{array}{l}\text { SCFA } \\
(\mathrm{mmol} / \mathrm{g} \mathrm{DM})\end{array}$ & $\begin{array}{l}\mathrm{PF}_{24} \\
\text { (mg DMD/mL gas) }\end{array}$ & $\begin{array}{l}\text { MCP } \\
(\mathrm{mg} / \mathrm{g} \mathrm{DM})\end{array}$ & $\begin{array}{l}\mathrm{GY}_{24} \\
\text { (gas/g DMD) }\end{array}$ \\
\hline FCO & ЕР0 & 0 & 6.64 & 8.73 & 586.2 & 643.7 & 4.98 & 5.30 & 697.5 & 188.8 \\
\hline \multirow[t]{3}{*}{ FCE } & $\mathrm{CE}$ & 0 & 6.89 & 8.88 & 596.6 & 616.3 & 5.11 & 5.27 & 708.4 & 189.8 \\
\hline & & 1 & 6.97 & 8.31 & 558.7 & 521.0 & 4.64 & 5.41 & 668.5 & 185.0 \\
\hline & & 3 & 6.91 & 8.80 & 591.3 & 536.7 & 5.05 & 5.29 & 702.8 & 189.1 \\
\hline \multirow[t]{3}{*}{ FCX } & CX & 0 & 6.72 & 8.04 & 541.8 & 604.3 & 4.43 & 5.45 & 650.8 & 183.5 \\
\hline & & 1 & 6.81 & 8.17 & 550.1 & 572.3 & 4.53 & 5.42 & 659.4 & 184.5 \\
\hline & & 3 & 6.83 & 8.42 & 566.3 & 546.0 & 4.73 & 5.37 & 676.5 & 186.4 \\
\hline \multirow[t]{3}{*}{ FXY } & $\mathrm{XY}$ & 0 & 6.88 & 8.59 & 577.5 & 524.7 & 4.87 & 5.32 & 688.3 & 187.9 \\
\hline & & 1 & 6.79 & 8.53 & 573.7 & 654.3 & 4.83 & 5.35 & 684.2 & 187.0 \\
\hline & & 3 & 6.80 & 9.50 & 637.2 & 581.0 & 5.62 & 5.16 & 751.0 & 193.9 \\
\hline $\begin{array}{l}\text { SEM } \\
P \text { value }\end{array}$ & \multicolumn{9}{|c|}{$P$ value } & 2.65 \\
\hline \multicolumn{11}{|l|}{ Enzyme Dose } \\
\hline Linear & & & .687 & .164 & .165 & .026 & .162 & .248 & .165 & .223 \\
\hline Quadratic & & & .580 & .141 & .139 & .487 & .043 & .033 & .039 & . 138 \\
\hline Fecal Source $\times$ & $\times$ Enzyme & Product & .020 & .017 & .171 & .050 & .017 & .025 & .017 & .024 \\
\hline $\begin{array}{l}\text { Fecal Source } \times \\
\text { Enzyme Do }\end{array}$ & $\begin{array}{l}\times \text { Enzyme } \\
\text { se }\end{array}$ & Product $\times$ & .136 & .578 & .573 & .014 & .575 & .644 & .573 & .645 \\
\hline
\end{tabular}

Abbreviations: CE, cellulase; CX, cellulase + xylanase (1:1); DM, dry matter; DMD, in vitro dry matter disappearance; FCE, fecal from horses fed cellulase; FCO, fecal from horses fed control diet; FCX, fecal from horses fed cellulase + xylanase (1:1); FXY, fecal from horses fed xylanase; GY 24 , gas yield at 24 hr of incubation; MCP, microbial crude protein production; $\mathrm{ME}$, metabolizable energy; OMD, in vitro organic matter digestibility; $\mathrm{PF}_{24}$, partitioning factor at 24 hr of incubation; SCFA, short-chain fatty acids; SEM, standard error of the mean; XY, xylanase. 
Fermentation of dietary carbohydrates produces mainly acetate, propionate, butyrate, and gases of $\mathrm{H}, \mathrm{CO}_{2}$, and $\mathrm{CH}_{4}$, with different proportions at different incubation times. In the present study, $\mathrm{CH}_{4}$ started to be produced at 10 hours of incubation with rapid increase to reach its peak concentration at the end of incubation, whereas gases started early at the beginning of the incubation which reflects the nature of produced gases during fermentation. Methane production for horses are between those for pigs and ruminants by the methanogenic Archaea, which represent the main hydrogenotrophic microbial community [29], with about 3 to $4 \%$ of the digestible energy or 2 to $3 \%$ of the gross energy intake. Salem et al [9] showed that CE and XY enzymes at $2-\mathrm{mL} / \mathrm{g}$ DM of the same substrate used in the present study decreased $\mathrm{CH}_{4}$ production, whereas $\mathrm{CE}+\mathrm{XY}$ mixture $(1: 1$ $\mathrm{vol} / \mathrm{vol}$ ) increased its production at 48 hours.

Inocula of FCX or FXY and without enzyme addition increased $\mathrm{CH}_{4}$ production compared with other treatments, even with enzyme addition. This means that within each treatment, the enzyme addition reduced $\mathrm{CH}_{4}$ production. Methane production depends on the quality of the diet fed. Feeding highly fibrous diets produces greater $\mathrm{CH}_{4}$ than when fed better quality forages [26]. This reflects expected better feed utilization with addition of enzyme to the mare's diet. Agazzi et al [24] showed that the mechanisms involved in the digestion and fermentation of plant cell wall component are very similar in both ruminants and equines; therefore, the probable mode of action in the ruminant may be applied to horses. Decreased $\mathrm{CH}_{4}$ production may be due to affected acetogens with enzyme addition, to compete or to cometabolize $\mathrm{H}_{2}$ for other process than its utilization with methanogens, thereby reducing $\mathrm{CH}_{4}$ formation and emissions [30]. Decreased $\mathrm{CH}_{4}$ can refer to decreased acetate and increased propionate productions resulting in reduced loss of energy to the host [30]. Reddish and Kung [31] have shown that supplementing fiber degrading enzymes in animal diets may improve feed utilization by enhancing fiber degradation and reducing $\mathrm{CH}_{4}$ production per unit of animal by-products [28].

\subsection{Fermentation Kinetic Parameters}

Fermentation parameters of $\mathrm{pH}, \mathrm{ME}, \mathrm{DMD}, \mathrm{SCFA}, \mathrm{PF}_{24}$, $\mathrm{MCP}$, and $\mathrm{GY}_{24}$ were fecal source and enzyme product dependent as interactions were observed. Xylanase addition increased DMD which may be related to enhanced attachment and colonization to the plant cell wall material by rumen microorganisms [28]. A synergism interaction between the endogenous and the exogenous enzymes applied has been considered as the most likely mode of action [32]. Salem et al [9] stated that the addition of CE, XY, and $\mathrm{CE}+\mathrm{XY}$ (the same preparations used in the present study) improved DMD of diets containing 50\% oat straw in vitro.

Increased SCFA and MCP productions were obtained with $\mathrm{XY}$ addition. The increased SCFA concentrations could be associated to an improved digestion of structural carbohydrates [23]. Tang et al [26] observed increased concentrations of SCFA due to enzymatic treatments for maize stover, rice straw, and wheat straw.
Improved fermentation kinetic can be explained based on increased in vitro cecal MCP production as a result of enzyme supplementation, which affected positively and modified microbial population of the digestive system and increased DM digestibility that help stimulate and increase the growth of cecal and colon bacteria. Partitioning factor is an index of the distribution of truly degraded substrate between microbial biomass and fermentation end products. The decreased PF with enzymes addition reflects less substrate converting into microbial biomass [23].

Enzyme had no effect on $\mathrm{pH}$, which could be due to the very high buffering capacity of the in vitro fermentation processes because four parts of buffer solution were added to one part diluted fecal fluid [6].

\section{Conclusions}

Addition of $\mathrm{XY}$ at $3-\mu \mathrm{L} / \mathrm{g}$ DM resulted in greater GP and improved fermentation kinetics. However, more studies are warranted to delineate the interactions between fecal source and different enzyme products at different doses on nutritive value and fermentation kinetics of mare's diet.

\section{Acknowledgments}

The authors acknowledge the financial support from the IAEA, Vienna, Austria (Research Contract Number MEX16307 within the D3.10.27 Coordinated Research Project). A.E.Kholif. thanks the National Council for Science and Technology (CONACyT, Mexico) and The World Academy of Sciences (TWAS, Italy) to support his postdoctoral fellowship at the Facultad de Medicina Veterinaria y Zootecnia, Universidad Autónoma del Estado de México, México.

\section{References}

[1] Rowe JB, Lees MJ, Pethick DW. Prevention of acidosis and laminitis associated with grain feeding in horses. J Nutr 1994;124:2742S-4S.

[2] Mungall BA, Kyaw-Tanner M, Pollitt CC. In vitro evidence for a bacterial pathogenesis of equine laminitis. Vet Microbiol 2001;79: 209-23.

[3] Khattab HM, Gado HM, Salem AZM, Camacho LM, El-Sayed MM, Kholif AM, Elshewy AA, Kholif AE. Chemical composition and in vitro digestibility of Pleurotus ostreatus spent rice straw. Anim Nutr Feed Technol 2013;13:507-16.

[4] Kholif AE, Khattab HM, El-Shewy AA, Salem AZM, Kholif AM, ElSayed MM, Gado HM, Mariezcurrena MD. Nutrient digestibility, ruminal fermentation activities, serum parameters and milk production and composition of lactating goats fed diets containing rice straw treated with Pleurotus ostreatus. Asian-austral J Anim Sci 2014;27:357-64.

[5] NRC. Nutrient requirements of horses. 6th ed. Washington, DC: National Academy Press; 2007.

[6] Lattimer JM, Cooper SR, Freeman DW, Lalman DL. Effect of yeast culture on in vitro fermentation of a high-concentrate or high-fiber diet using equine fecal inoculum in a Daisy II incubator. J Anim Sci 2007;85:2484-91.

[7] Salem AZM, Alsersy H, Camacho LM, El-Adawy MM, Elghandour MMY, Kholif AE, Rivero N, Alonso MU, Zaragoza A. Feed intake, nutrient digestibility, nitrogen utilization and ruminal fermentation activities of sheep fed Atriplex halimus ensiled with developed enzyme cocktails. Czech J Anim Sci 2015;60:185-94.

[8] Togtokhbayar N, Cerrillo SMA, Jigjidpurev S, Shinekhuu J, Urantulkhuur D, Nergui D, Elghandour MMY, Odongo NE, Kholif AE. Effect of exogenous xylanase on rumen in vitro gas production and degradability of wheat straw. Anim Sci J 2015;86:765-71. 
[9] Salem AZM, Elghandour MMY, Kholif AE, Odongo NE, Jiménez FJP, Montes-de-Oca R, Domínguez IA, Dibarrat JA. The effect of feeding horses a high fiber diet with or without exogenous fibrolytic enzymes supplementation on nutrient digestion, blood chemistry, fecal coliform count, and in vitro fecal fermentation. J Equine Vet Sci 2015;35:735-43.

[10] Khattab HM, Gado HM, Kholif AE, Mansour AM, Kholif AM. The potential of feeding goats sun dried rumen contents with or without bacterial inoculums as replacement for berseem clover and the effects on milk production and animal health. Inter J Dairy Sci 2011; 6:267-77.

[11] Alsersy H, Salem AZM, Borhami BE, Olivares J, Gado HM, Mariezcurrena MD, Yacuot MH, Kholif AE, El-Adawy M, Hernandez SR. Effect of Mediterranean saltbush (Atriplex halimus) ensilaging with two developed enzyme cocktails on feed intake, nutrient digestibility and ruminal fermentation in sheep. Anim Sci J 2015;86:51-8.

[12] Murray JMD, Longland A, Davies DR, Hastie PM, Moore-Colyer M, Dunnett C. The effect of enzyme treatment on the nutritive value of lucerne for equids. Livest Sci 2007;112:52-62.

[13] Tisserand JL. Microbial digestion in the large intestine in relation to monogastric and polygastric herbivores. Acta Vet Scand Suppl 1989; 86:83-92.

[14] Murray JMD, Longland AC, Moore-Colyer MJS, Dunnett C. The effect of enzyme treatment on the in vitro fermentation of lucerne incubated with equine faecal inocula. Br J Nutr 2005;94:771-82.

[15] Robyt JF, Whelan WJ. Reducing value methods for maltodextrins: 1. Chain-length dependence of alkaline 3,5-dinitrosalicylate and chain length independence of alkaline copper. Anal Biochem 1972;45: 510-6.

[16] Theodorou MK, Williams BA, Dhanoa MS, McAllan AB, France J. A simple gas production method using a pressure transducer to determine the fermentation kinetics of ruminant feeds. Anim Feed Sci Technol 1994;48:185-97.

[17] Goering MK, Van Soest PJ. Forage fiber analysis (apparatus, reagents, procedures and some applications). Agriculture Handbook, No 379. Washington, DC: Agricultural Research Service, USDA; 1970.

[18] Co SAS. User's guide: statistics, version 9.0. Cary, NC: SAS Institute; 2002.

[19] France J, Dijkstra J, Dhanoa MS, López S, Bannink A. Estimating the extent of degradation of ruminant feeds from a description of their gas production profiles observed in vitro: derivation of models and other mathematical considerations. Br J Nutr 2000;83:143-50.

[20] Menke KH, Raab L, Salewski A, Steingass H, Fritz D, Schneider W. The estimation of the digestibility and metabolizable energy content of ruminant feeding stuffs from the gas production when they are incubated with rumen liquor in vitro. J Agr Sci 1979;93:217-22.
[21] Blümmel M, Steingss H, Becker K. The relationship between in vitro gas production, in vitro microbial biomass yield and $15 \mathrm{~N}$ incorporation and its implications for the prediction of voluntary feed intake of roughages. Br J Nutr 1997;77:911-21.

[22] Getachew G, Makkar HPS, Becker K. Tropical browses: contents of phenolic compounds, in vitro gas production and stoichiometric relationship between short chain fatty acid and in vitro gas production. J Agr Sci 2002;139:341-52.

[23] Elghandour MMY, Vázquez Chagoyán JC, Salem AZM, Kholif AE, Martínez Castañeda JS, Camacho LM, Buendía G. In vitro fermentative capacity of equine fecal inocula of 9 fibrous forages in the presence of different doses of Saccharomyces cerevisiae. J Equine Vet Sci 2014;34:619-25.

[24] Agazzi A, Ferroni M, Fanelli A, Maroccolo A, Invernizzi G, Dell'Orto V, Savoini G. Evaluation of the effects of live yeast supplementation on apparent digestibility of high fiber diet in mature horses using the acid insoluble ash marker modified method. J Equine Vet Sci 2011; 31:13-8.

[25] Mao Hui-ling, Mao Hua-long, Wang JK, Liu JX, Yoon I. Effects of Saccharomyces cerevisiae fermentation product on in vitro fermentation and microbial communities of low-quality forages and mixed diets. J Anim Sci 2013;91:3291-8.

[26] Tang SX, Zou Y, Wang M, Salem AZM, Odongo NE, Zhou CS, Han XF, Tan ZL, Zhang M, Fu YF, Huang SQ, He ZX, Kang JH. Effects of exogenous cellulase source on in vitro fermentation characteristics and methane production of crop straws and grasses. Anim Nutr Feed Technol 2013;13:489-505.

[27] Almaraz I, González SS, Pinosrodríguez JM, Miranda LA. Effects of exogenous fibrolytic enzymes on in sacco and in vitro degradation of diets and on growth performance. Ital J Anim Sci 2010;9:6-10.

[28] Nsereko VL, Beauchemin KA, Morgavi DP, Rode LM, Furtado AF, McAllister TA, Iwaasa AD, Yang WZ, Wang Y. Effect of a fibrolytic enzyme preparation from Trichoderma longibrachiatum on the rumen microbial population of dairy cows. Can J Microbiol 2002;48:14-20.

[29] Wolin MJ, Miller TL, Stewart CS. Microbe-microbe interactions. In: Hobson PN, Stewart CS, editors. The rumen microbial ecosystem. second ed. London, UK: Chapman \& Hall; 1997. p. 467-91.

[30] Stewart CS, Flint HJ, Byrant MP. The rumen bacteria. In: Hobson PN, Stewart CS, editors. The rumen microbial Ecosystem. New York, NY, USA: Blackie Academic and Professional; 1997. p. 10-55.

[31] Reddish MA, Kung LJ. The effect of feeding a dry enzyme mixture with fibrolytic activity on the performance of lactating cows and digestibility of a diet for sheep. J Dairy Sci 2007;90:4724-9.

[32] Morgavi DP, Beauchemin KA, Nsereko VL, Rode LM, Mcallister TA, Iwaasa AD, Wang Y, Yang WZ. Resistance of feed enzymes to proteolytic inactivation by rumen microorganisms and gastrointestinal proteases. J Anim Sci 2001;79:1621-30. 